DOI: 10.2478/ausp-2020-0019

\title{
Erika-Mária Tódor et al. (eds) Alkalmazott nyelvészeti szótár
}

(A két- és többnyelvüség alapfogalmai) / Dicționar de lingvistică aplicată (Conceptele fundamentale ale bi- şi multilingvismului) / Dictionary of Applied Linguistics (Basic

Concepts of Bi- and Multilingualism)

Presa Universitară Clujeană / Kolozsvári Egyetemi Kiadó /

Cluj University Press, 2019

\author{
Review by \\ Enikő PÁL
}

Sapientia Hungarian University of Transylvania (Cluj-Napoca, Romania)

Department of Human Sciences, Miercurea Ciuc

paleniko@uni.sapientia.ro

The need for an unequivocal linguistic terminology has been observed since the early 1920s. At that time, several linguists faced difficulties in drafting their work, either making lexicographic tools (see Ştefănoaia 2015) or designing new theoretical frameworks. As the French linguist of the time, Henri Frei, pointed it out in the introductory note of his La grammaire des fautes [The Grammar of Mistakes] ([1929] 2007), "linguistic terminology is in full anarchy in all countries" (Frei 2007: 9). Since then, not only terminology has enriched in number, alongside the emergence of new scientific fields and linguistic schools, but old terminology has been reassigned as different research domains have come to blend on the interface of interdisciplinarity. Nowadays, linguistic terminology is probably as heterogeneous as never before. This lack of unity has resulted in a great deal of uncertainty in using specific terms, confusing uninitiated readers, and occasionally making even specialists difficult to understand each other. ${ }^{1}$

Given this circumstance, the trilingual dictionary of applied linguistics we are reviewing particularly comes in handy when one is engaged in finding certain interlingual consistency. The volume in question aims not only at satisfying the

1 On the "calibration" of terms and the principles and conventions to be respected in the comparative (and contrastive) endeavour of "terminological calibration", see Swiggers 2010. 
need for a clear definition of the terminology included within but also at reaching a common sense of the selected concepts by harmonizing the meanings adopted in different languages (see "Introductory note", p. 13). Such an endeavour is quite laborious since the culture-specific connotations attached to the semantic sphere of the concepts in question make it rather difficult to find terminological equivalents. On the other hand, mismatches may also occur due to the diversity of linguistic theories which have coined the respective terms since they may have been developed within a particular theoretical framework, not entirely shared in all of the languages. Then again, certain terms may have a reduced use in a given language or they may not be in use at all. Such interlingual differences may pose serious problems to any researcher trying to disentangle the array of linguistic theories and its related terminology and to find correspondences.

This latter goal is fulfilled by the present dictionary, designed by a small research group of six scholars (Krisztina Bartha, Attila Benő, Zsuzsanna Dégi, Sára Magyari, Enikő Tankó, and Erika-Mária Tódor), who carried out their project with the financial support of the Scientific Research Department of Sapientia Hungarian University of Transylvania in Cluj-Napoca. The glossary of scientific terms focuses on understanding bi- and multilingualism from the perspective of (applied) linguistics and language pedagogy. As suggested in its subtitle, it covers the basic concepts related to the aforementioned research fields, offering an overview of the most significant and frequently used terms. Thus, the selective book of terminology proves to be a useful tool for both active researchers of the field and the (still) unspecialized reader.

The terms and concepts discussed in the present dictionary circumscribe issues pertaining to the vast domains of second language acquisition (including concepts such as mother tongue vs. second language or non-native language; critical period, threshold hypothesis, silent period, etc.), bilingualism and its linguistic reflexes (covering notions such as diglossia, linguistic interference, lexical calque, loan word, loanblend, loanshift, code-mixing, code-switching, etc.), certain broader psycholinguistic phenomena (such as language acquisition device, speech comprehension, speech perception, phonological awareness, conceptualization, etc.), and sociolinguistic issues dealing with, e.g., language policy (clarifying concepts such as linguistic landscape or schoolscape), among others. The volume encompasses 48 terms and concepts altogether, ranging from the relatively simple ones, such as false friends or register, to the most complex of concepts such as basis of articulation (or articulatory setting) or the linguistic image of the world.

The volume offers a trilingual description of each term and concept included. These definitions are based on an extensive study of the relevant and up-to-date scientific literature. Each entry is structured into three main parts. The term itself is followed by its general explanation. The theoretical overview of the notions is then followed by a list of the references used to explain each particular concept. After 
the employed literature, there comes a separate section of suggestions for further reading on the given topic (term and concept). Each term and concept is discussed first in Hungarian, followed next by its Romanian and, finally, by its English version. So, the alphabetical order in which the terms are enlisted follows the initial letters of the Hungarian terms. In order to facilitate the use of the dictionary and to easily find any particular term one might be interested in, at the end of the volume there is a list of content words with the indication of the pages they can be found on. This makes the search more efficient and less troublesome for the reader to pinpoint a given term whether in Hungarian, Romanian, or English.

When assessing the value of polyglot dictionaries - otherwise very cultivated, especially since the first half of the $20^{\text {th }}$ century, yet quite neglected in lexicographical analysis -, the most likely considered benchmarks to evaluate its worth would involve criteria such as: the selection of terms and concepts, their descriptive approach, organizing the corpus, the languages engaged, and perhaps the manner of indexing (Bursuc 2015: 176; see also Pricop 2017: 518). On the macro-structural level, any specialized dictionary might grasp the attention by the selection of the vocabulary included as well as by its disposition. In this respect, one of the strengths of the reviewed volume is that it provides a stimulating selection of the most commonly used, yet problematic, terms and concepts of applied linguistics, embracing a wide range of scientific domains. Thus, the book is notable for its real practical use as it gives a brief but in-depth account of the basic concepts of biand multilingualism, summarizing the most recent and relevant literature on each and every word entry. By displaying the material in sequence, the explanations in the three languages following one after the other, users may immediately set the different denominations side by side. On the micro-structural level, a closer look might be given to the word entries themselves. The explanations given for each term and concept provide a quick way to get acquainted not only with the notion itself but also with the views of different experts of the field. The definitions themselves mainly follow the analytical or Aristotelian definitional format, which has a long tradition in lexicographical works (see Adamska-Salaciak 2015: 324), probably due to its efficiency. Thus, the intensional definitions usually start with specifying the genus proximum of the term (i.e. the scientific field(s) the given term belongs to), followed by its differentiae specificae (i.e. those characteristics which discriminate the term and concept). ${ }^{2}$ In addition, many valuable references are given as to where the concepts are discussed at greater length.

Overall, the dictionary succeeds in achieving its twofold aim, stated in its "Introductory note" - namely, it provides readers "with comprehensive explanations

2 Here is just one example. Under the entry silent period, for instance, we find the following explanation: "Term related to the domain of L1 and L2 acquisition [...] It refers to the early stages of second language acquisition (SLA) during which learners produce no language at all or the most minimal language [...]" (p. 185). 
that allow them to use the given terms correctly", and it also offers "reliable and motivating starting points for those who wish to deal with such questions" (p. 14). The volume presented in this review stands out as a unique piece of work not only due to its trilingual nature, making the corpus available in Hungarian, Romanian, and English (a somewhat less common language combination), but also due to the clarity, conciseness, and precision of the notional definitions while enriching the line of dictionaries of linguistic terms.

\section{References}

Adamska-Salaciak, Arleta. 2015. Dictionary definitions: Problems and solutions. Studia Linguistica Universitatis Iagellonicae Cracoviensis 129(4): 323-339.

Bursuc, Alina-Mihaela. 2015. Observații privind dicționarele poliglote de termeni lingvistici [Remarks on multilingual dictionaries of linguistic terms]. In Rodica Zafiu-Isabela Nedelcu (eds), Variația lingvistică: probleme actuale. Actele celui de-al 14-lea Colocviu Internațional al Departamentului de Lingvistică [Linguistic Variation: Current Problems. Proceedings of the $14^{\text {th }}$ International Colloquium of the Department of Linguistics], 167-176. Bucharest: Editura Universității din Bucureşti.

Frei, Henri. 2007. La grammaire des fautes [The Grammar of Mistakes]. Rennes: Editions Ennoia ( $1^{\text {st }}$ edition: Paris: P. Geuthner, 1929).

Pricop, Alina-Mihaela. 2017. Dicționarele terminologice multilingve. Clasificare şi tip dominant [Multilingual dictionaries of terminology. Classification and dominant type]. Limba română [Romanian Language] 66(4): 518-526.

Swiggers, Pierre. 2010. Terminologie, terminographie et metalangage linguistiques: quelques reflexions et propositions [Linguistic terminology, terminography, and metalanguage: Some reflections and suggestions]. Revue roumaine de linguistique 55(3): 209-210.

Ştefănoaia, Ioana. 2015. Din istoria preocupărilor referitoare la terminologia lingvistică. Reprezentanți ai lingvisticii franceze [From the history of linguistic terminology. The representatives of French linguistics]. Limba română. Revistă de ştiință şi cultură [Romanian Language. Journal of Science and Culture] 25(3-4): 59-73. 